\title{
Innovation Challenges and Opportunities in European Rural SMEs
}

\author{
Inga Uvarova \\ BA School of Business and Finance \\ Krišjāña Valdemāra st. 161, LV-1013 Riga, Latvia \\ Alise Vitola \\ Hotel School Riga \\ Smilsu st. 3, LV-1050 Riga, Latvia \\ cross $^{\text {ref }}$ http://dx.doi.org/10.5755/j01.ppaa.18.1.23134
}

\begin{abstract}
Adoption of innovation plays a crucial role in the transformation of the countryside towards a knowledge economy. However, rural SMEs experience various obstacles that hinder the adoption of innovation. The aim of this paper is to identify the main challenges and opportunities for the introduction of innovation in rural SMEs. The evidence is drawn from relevant literature and stakeholder discussions covering six European countries (Bulgaria Czech Republic, Hungary, Italy, Latvia and Slovenia). The main challenges in adopting innovation in rural SMEs are shortcomings in the environment for innovation, inappropriate innovation policies and support measures, lack of knowledge and skills within companies, difficulties to hire a new skilled work force and low competitiveness compared to urban counterparts. Consequently, policy recommendations are proposed for promoting innovation in rural SMEs by focusing on cooperation and networking, information and training, innovation support programmes, marketing and sales promotion and availability of workforce.
\end{abstract}

Raktažodžiai: innovation, competitiveness, SMEs, business model, rural policy.

Keywords: inovacijos, konkurencingumas, MVI, verslo modelis, kaimo politika.

\section{Introduction}

Rural regions in Europe have undergone significant changes in the recent decades. The role of traditional rural industries, such as farming, forestry and fishery, mining and quarrying, as well as manufacturing of food and wood products, is declining. Although agriculture still accounts for a significant proportion of the 
employment in remote rural areas, rural economies move away from traditional rural sectors towards more knowledge intensive sectors and the service economy. If the rural regions can successfully adapt to the knowledge economy through job creation in a broad mix of sectors, then they can avoid the decline by building a 'new rural economy' (Cowie et al. 2013, Fieldsend 2013). Thus, the rural economies now have a greater need for globally-oriented, entrepreneurial firms than before (Galloway 2007).

The adoption of innovations plays a crucial role in the transformation of countryside from traditional rural sectors towards a knowledge economy. However, rural SMEs experience various challenges that hinder the adoption of innovation due to smaller size, lower productivity, remote location, small local market, lack of innovative spirit, difficulties to attract labour force and other reasons. On the other hand, the economy of the 21st century offers various opportunities also for rural SMEs by diversifying business, adopting innovative technologies and new business models, as well as employing the opportunities provided by new trends in the economy, such as the bioeconomy, the social economy and the sharing economy.

The aim of this paper is to explore the main challenges and opportunities for the introduction of innovation in the European rural small and medium enterprises (hereinafter SMEs) and consequently to propose recommendations for the public policy. The objectives of this paper are: 1) to undertake a desk research on the main challenges and opportunities for the introduction of innovation in rural SMEs by surveying relevant literature; 2) to gather the opinion of stakeholders on the main challenges and opportunities for the introduction of innovation; 3) to propose policy recommendations in order to provide incentives for the introduction of innovation in rural SMEs.

The research covers seven rural regions located in six European Union (hereinafter EU) countries - Lombardy and Molise in Italy, Pardubice in Czech Republic, Nyugat-Dunantul in Hungary, Zemgale in Latvia, Gorenjska in Slovenia and Stara Zagora in Bulgaria. The selection of regions is geographically balanced and includes more developed regions, less developed regions and transition regions. The research employs qualitative research methods such as desk research, focus groups and semi-structured interviews. This paper has been prepared based on the research conducted within the Interreg Europe project "Regional policies for innovation driven competitiveness and growth of rural SMEs - INNOGROW" (hereinafter INNOGROW project).

This paper is structured as follows. The next two sections offer a theoretical background on main challenges and opportunities for the introduction of innovations in rural SMEs. The fourth section explains the methods and data used. The fifth section presents the results of the research and proposes policy recommendations to provide incentives for the local rural SMEs to adopt innovations. The sixth section concludes.

\section{Challenges faced by the rural SMEs}

The policymakers have recognised a need for an enterprising countryside with 
sustainable agriculture and environment, as well as thriving and inclusive rural communities (Smallbone et al. 2003). Therefore it is important to identify the challenges that rural SMEs face due to their remote location and propose solutions accordingly.

Researchers highlight that rural areas are characterised by a comparatively high share of small enterprises. This is regarded as an obstacle for the successful development of rural areas as these economic subjects are not productive and are more reluctant to innovations and the diversification of economic activities. Consequently, this results in a lower productivity rate of SMEs, a lower amount of foreign investment, a lower GDP and a lower income (Cimdina 2014, Kruszilicika et al. 2014, Ionela et al. 2015, Tarasovych 2017).

A limited scale and scope of the local market and a high distance from the major national and international markets is one of the competitive disadvantages faced by rural SMEs. Therefore, they should be particularly active in seeking external markets and improving their marketing strategies. Focusing on niche products is another way to overcome this challenge (Kubickova et al. 2017, Smallbone et al. 2003, Smallbone and North 1999). Furthermore, information and communication technologies (ICT) allow them to reach customers or business partners all over the world. The Internet might be used for trading, brand building, advertising and marketing, as well as for business networking (Galloway 2007).

A lack of innovative spirit, especially amongst companies in the traditional rural sectors, is another challenge faced by the rural SMEs (Fieldsend 2013). The reasons for establishing a business in rural regions often differ from the reasons to start a business in cities, with rural regions having a larger share of "lifestyle" rather than "entrepreneurial" firms (Galloway 2007). Moreover, many of the rural SMEs see their mission in not only providing profit, but also fulfilling wider socioeconomic goals, such as maintaining the traditional lifestyle, landscape quality and wildlife, safeguarding the archaeological and historic features of the territory, and providing 'ecosystem services' such as biodiversity and climate change mitigation (Tate 2010, Fieldsend 2013).

Furthermore, as the population in rural regions is often ageing faster than in urban areas, there is a concern regarding the business succession, especially in more traditional rural sectors as agriculture and manufacturing due to the lack of potential managers to take over businesses. Also the loss of young people in the rural regions reduces the local "dynamic" (Fieldsend 2013, Lopez and Pastor 2015).

Limited opportunities to attract workforce on the one hand, and relatively low wage levels and high employee loyalty on the other hand reduce incentives to invest in technologies, especially in more craft-based sectors (Kubickova et al. 2017, Fieldsend 2013, Smallbone and North 1999). In contrast, those SMEs that choose to invest in technologies point to the mismatch between the job offers and the qualifications of the locally-available labour force manifesting as a shortage of skilled labour. Rural SMEs have a lower probability to outsource and cooperate, compared to their urban counterparts, as other companies, research and development facilities, 
educational institutions and business support providers (accountants, law offices etc.) are located further away (Smallbone et al. 2003, Smallbone and North 1999)

An access to suitable training is typically more challenging for rural SMEs, as the low population density inevitably makes it inevitably difficult to create a critical mass for providing training. As a result, rural SMEs have a lower level of knowledge and skills, including lower technological, management and ICT competences. Moreover, training is not often adjusted to the needs of local businesses and the labour market. Also business support services are less accessible for rural SMEs, compared to their urban counterparts, and often do not comply with their needs (Fieldsend 2013, Smallbone and North 1999).

Last but not least, the rural SMEs tend to be smaller as companies on average; rural SMEs have a higher proportion of microbusinesses and one-person businesses. Thus, rural SMEs are likely to be less able to meet their development needs from their own internal resources (Smallbone et al. 2003, Smallbone and North 1999). Also shortage in infrastructure, administrative barriers and unfavourable taxes hamper the growth of SMEs in rural regions (Kubickova et al. 2017, Fieldsend 2013).

\section{Opportunities for rural SMEs}

There are a number of opportunities for rural SMEs. Multifunctional agriculture allows the diversification of agricultural production via the introduction of complementary activities. While agriculture is kept as the primary source of income, other business activities are introduced in the farm, e.g. production of bio-energy, tourism, educational activities and the provision of cultural services. Educational farms offer various services related to the development of skills and knowledge for their customers, whereas holiday farms offer therapy, relaxation and leisure in an authentic rural space (Lanfranchi and Giannetto 2014).

Also rural tourism and agro-tourism offer new opportunities. Rural tourism is associated with services using local resources, often related to the natural and historical heritage of the rural areas. Agro-tourism, a vital part of rural tourism, includes visits to farms and other agricultural enterprises, which demonstrate agricultural methods, provide tasting of their products or exploit local resources for entertaining tourists within the farm (Ionela et al. 2015, Cimdina 2014). Likewise, rural areas are important tourist destinations for green and "slow tourism". The exploration of nature in combination with self-experiencing and visits to local farms, craftsmen and producers are demanded tourist attractions in the "slow tourism" destinations (Zawadzka 2017).

Social farming occurs, when enterprises besides the profitability goals aim at performing social functions, e.g. by involving vulnerable or disadvantaged groups, by preventing depopulation in remote rural areas or by other means contributing for quality of life in rural areas (Lanfranchi and Giannetto 2014). As the rural SMEs have a limited choice of employees among the local people, they are motivated to employ socially disadvantaged groups, e.g. people with disabilities or people in the preretirement and retirement age. In the long-term there are a number of advantages 
related to the diversity management of the workforce, because a diverse workforce understands better the variety of customers and the market, it generates new ideas and it maintains the productivity (Sumedrea 2017, Wondrak and Segert 2015, Tisserant 2013, Hanappi-Egger 2012).

Another opportunity for local and agro food producers and the craftsmen lies in the niche market of local authentic products due to the availability of local material and historical production traditions. However, the fact that these producers often target relatively small markets, limits their growth. Therefore, it is important to form a pool of local producers and craftsmen which collaborate and not compete with each other (Cei et al. 2017, Arnone \& Cavallaro 2016).

Territorial marketing plays an important role in shaping the image of rural areas and residents. Rural areas are characterised by a large number of small enterprises that alone are not able to carry out significant marketing and communication activities and thus reach large markets. To overcome this challenge, rural areas should provide branding of a particular rural area with its unique features, advantages and resources. Territorial branding is not a new concept, however this practice is not widely applied within rural areas and still has an unused potential. Local or regional authorities or other local action groups of civil society shall take the leading initiative in such marketing activities (Ceapraz and Delhoume 2017, Tarasovych and Tamuliene 2017, Zawadzka 2017).

Furthermore, the bioeconomy is shaping rural areas towards environmentally friendly and sustainable growth, which might significantly contribute to the competitiveness of rural SMEs. Bioeconomy opportunities of rural SMEs include the production and distribution of agricultural products, the production of safe and wellbalanced food and the reduction of waste and greenhouse gas emissions (Adamowicz 2017, Miceikiene 2017).

Also sharing economy provides new opportunities for the rural SMEs. The sharing economy is based on the idea that someone having assets (both material and immaterial), which are not used in full capacity, may share these assets with others that are willing and able to use these resources within a limited period of time. An important element of sharing economy is social networking and technologies that provide collaboration opportunities. Digital technologies through online platforms ensure an access to networking and partnering on a global scale, putting together demand and supply and providing new dissemination and sales promotion opportunities (Privitera 2016, Bonciu and Balgar 2016, Szetela and Mentel 2016).

Development of strong and dynamic managerial capabilities to seek and explore new opportunities in the changing market conditions is essential for entrepreneurs. Entrepreneurs should be not only proactive in developing new business models, but more importantly able to implement them by rearranging business processes and allocating necessary resources. Learning and knowledge sharing between businesses should be encouraged, as rural SMEs are reluctant to innovation and change (Teece 2017, Singh and Bhowmick 2015, Lopez and Pastor 2015).

Knowledge/know-how sharing is also possible through the establishment of co- 
creation or co-working spaces. Innovation labs, hubs and other co-working spaces encourage researchers, entrepreneurs, public authorities and any citizen to work together in creating and testing new products or services. People using the same facilities are forming new internal or external networks that inspire new ideas and the innovation process in general (Felicetti 2016, Szetela and Mentel 2016).

New business models encourage SMEs to think about collaboration that could facilitate their business and improve their competitiveness. SMEs can work together to improve the distribution channels and logistics and collaborate more effectively with distribution networks, retail chains or other large customers. SMEs can also create a partnership to attract highly qualified employees or, in general, work together on the solutions to tackle the lack of workforce. However, it is not easy for SMEs to build, manage and scale up such partnerships, which may open up access to larger clients, widen the customer segment and attract financing (Connect to Grow 2016). While the surroundings of urban/ metropolitan areas provide natural possibilities for creating partnerships by having a large number of individuals, enterprises and organisations relatively close to each other, rural areas are under-served because of the physical distance between actors. Therefore, networking and collaboration of different stakeholders of rural areas needs to be encouraged and facilitated.

\section{Methods and data}

This research covers seven regions located in six EU countries - Italy (Lombardy and Molise), Czech Republic (Pardubice region), Latvia (Zemgale), Slovenia (Gorenjska), Hungary (Nyugat-Dunantul) and Bulgaria (Stara Zagora). This selection includes regions from the North (Zemgale), Central (Pardubice region, Gorenjska and Nyugat-Dunantul) and South (Bulgaria, Italy) of Europe, less developed regions (Pardubice, Zemgale, Nyugat-Dunantul and Stara Zagora), transition regions (Molise) and more developed regions (Lombardia and Gorenjska) according to the classification of the EU Cohesion policy.

Six stakeholder meetings were organised in these locations to discuss challenges, opportunities and factors influencing adoption of innovations in rural SMEs. The participants of the stakeholder meetings were also asked to propose recommendations for facilitating innovation in rural SMEs. Participants of the stakeholder meetings included the representatives of local SMEs, municipalities, public regional bodies, national policy making bodies, social partners, higher education and research institutions, non-governmental organisations and business professionals. In total, 215 participants took part in the meetings. 16 people attended the meeting in Lombardia (Italy), 22 people in Molise (Italy), 30 people in Pardubice region (Czech Republic), 31 people in Zemgale (Latvia), 34 people in Gorenjska (Slovenia) and 41 people in Stara Zagora (Bulgaria). The average number of participants reached 31 per meeting. The stakeholder meetings took place from November 2016 until March 2017. Each meeting started with an introduction of the INNOGROW project and an outline of types of innovations and new business models of rural SMEs. Good practise examples were presented. Then the participants formed small groups with 6-12 people for a 
focus group discussion on barriers, opportunities and factors that induce or hinder rural SMEs to adopt innovations followed. After that policy recommendations were proposed in groups to facilitate the adoption of innovations in rural SMEs. Finally, each group presented the results of their work and provided feedback to their peers.

Additionally to the stakeholder discussions in focus groups, three semi-structured interviews were conducted with rural development experts in a written form. Experts from partner organisations of the INNOGROW project - the University of Newcastle upon Tyne, the Stara Zagora Regional Economic Development Agency and the Chamber of Commerce of Molise - were interviewed. The aim of these interviews was to test the validity of the conclusions included in this report.

\section{Results}

The results of the focus groups and semi-structured interviews show that the main barriers and challenges that the rural SMEs face can be classified into five groups: shortcomings in the environment for innovation, inappropriate innovation policies and support measures, lack of knowledge and skills within companies, difficulties to hire new skilled work force and weak capacity to compete/low competitiveness.

Shortcomings in the environment for innovation include the lack of innovation culture and a low interest in innovative solutions. Large part of rural SMEs do not realise the need to change their business model and adapt to the rapidly changing market conditions. These conclusions comply with the previous research (e.g. Fieldsend 2013, Galloway 2007). As a result, the business demand for innovation is not meeting the market expectations. On the other hand, the interaction between business, academia and the public sector is not close enough, impeding the development and commercialisation of innovation. Businesses should be more active in demanding innovative solutions from scientists. Scientists should focus more on the needs of businesses instead of providing technical solutions, which might not be economically sustainable for everyday use in the rural SMEs.

Several participants of the stakeholder meetings stressed the fragmentation and discontinuity of innovation policies and support measures. Public institutions often lack the competence to build efficient innovation programmes for rural SMEs. Another challenge is the development of rural SMEs that are not agricultural companies, because the rural development programmes largely focus on the agriculture sector. Administrative burdens within the innovation support measures were also often mentioned as an important drawback.

Another barrier for the innovation in rural SMEs comes from the lack of knowledge and skills within the companies. Rural SMEs lack information and knowledge on how to use innovative solutions in order to integrate them into their business model. The number of business advisers and experts for rural SMEs is insufficient and the exchange of good practices between rural SMEs is poor. This has been previously mentioned also by Fieldsend (2013) and Smallbone and North (1999). Moreover, farmers and other small business owners often lack time to look 
for education opportunities and to participate in training, especially if seminars and consultations are organised in periods when farmers are busy working in the field. An important barrier for innovation in rural SMEs is also the lack of ICT skills, especially for the older generation, which impedes the SMEs use of new technologies. In most cases the introduction of innovative solutions requires financial investments in new equipment, staff, software and/or marketing. Usually such funding is not available from internal sources, thus rural SMEs have to look for external private or public funding. These finding agree to the conclusion of Smallbone et al. (2003) and Smallbone and North (1999). Unfortunately, rural SMEs often lack a general knowledge on funding instruments, including the support measures and alternative funding options, such as business angels, venture capital funds, crowdfunding platforms etc.

An important challenge for rural SMEs is the difficulties in hiring skilled workforce. The lack of highly qualified staff in the countryside, as well as a high turnover of employees in the rural areas, which are located close to the cities, was mentioned as one of the most important problems that hinder the adoption of innovation. Another challenge that was raised is attracting young people to rural areas, as they often do not see rural business as an appealing alternative to the city life. The loss of young people was stressed also by Fieldsend (2013) and Lopez and Pastor (2015).

Many participants of the stakeholder meetings mentioned their insufficient capacity to compete as a barrier for the introduction of innovative technologies and new business models. In some areas the high competition causes rural SMEs to focus on low prices instead of quality improvements. In comparison to big corporations, rural SMEs are not able to invest much in advertising their high-quality products. Moreover, rural SMEs have a limited capacity to negotiate a fair price for their products with the large retail chains and franchise brands. Therefore, many small producers focus on direct sales, which limit their market expansion possibilities.

Other barriers and challenges for the introduction of innovative technologies and new business models in rural SMEs, which were mentioned by the participants of stakeholder meetings and experts, included limited business diversification, the uncertain economic situation and insufficient investment in infrastructure, low-quality ICT infrastructure and lack of territorial coordination of investments.

Regarding the opportunities to promote innovations and new competitive business models within rural SMEs, the focus groups outlined context factors as the multifunctionality of rural SMEs, new forms of governance for rural areas and innovation of traditional products. The participants argued that it is important to employ a bottom-up approach in rural areas by listening to the local communities and talking to the workers.

The cooperation between farms should be strengthened, allowing optimizing production, marketing and other costs and reducing taxes for farms that play a multifunctional role. Some farms, for example, are preserving the cultural landscape and are contributing to biodiversity, tourism and the quality of life. Consequently, the 
stakeholders proposed support measure for rural SMEs that focus on such areas as the ecosystem services, urban-rural partnerships and improvement in the local governance, support for selling local products in local and international markets (e.g. support for distributing products in the supermarket chains).

The stakeholders also stressed that it is crucial to provide rural development counsellors with an access to educational programs and to strengthen their role in advising, motivating and enlisting farmers in relevant training programmes. Special training programs should be provided for older farmers on the use of modern ICT technologies and the time of training must be adjusted to the calendar of farmers by organising training in the time periods where there is less or no work on the fields.

Information should be distributed about new technologies and innovative business models among rural SMEs. Special events should be organised for presenting the benefits of the introduction of innovations and new business models in rural SMEs. Thus managers and owners of rural SMEs will be encouraged to change attitude towards innovations and adopt them into their own businesses.

The stakeholders highlighted the necessity to provide more information to rural SMEs about the support measures financed by various sources, first of all the European Union. It was also stressed that many rural SMEs lack experience and information about the availability and possibilities of using alternative funding sources, such as business angels, venture capital funds, crowd funding platforms and others.

Innovation support programmes should focus on innovative rural SMEs, supporting biodynamic and organic products and innovative marketing. Consultative support should be provided for the innovation chain and the protection of intellectual property. The participants also advised to simplify the process to receive public funding for new technologies, as in many cases the technologies are being tested and adjusted during the process of project implementation and therefore it is not possible to provide a very detailed technical description of a technology when submitting the proposal.

Also non-financial support like "enterprise hubs" and business advisory may encourage rural SMEs to exchange their traditional approach for innovations. The "enterprise hubs" provide SMEs with shared office space, which is rented under more favourable conditions, with access to a pool of shared support services in order to reduce overhead costs of rural SMEs, with availability of professional business support or advices, and with internal (among SMEs within the hub) and external (with other stakeholders outside the hub) networking opportunities.

According to the stakeholders, new opportunities are also provided by the digital communication, which can create new approaches of marketing. For example, in Molise region stakeholders proposed to revitalize and give a new value to the Chamber of Commerce of Molise brand "Piacere Molise" in order to promote products produced in the Molise region.

The results of the focus groups and the analysis of relevant literature allows to identify five categories of activities where public policy should be improved to 
facilitate the adoption of innovations in rural SMEs: cooperation and networking, information and training, innovation support programmes, marketing and sales promotion in international markets and, finally, availability of workforce. According to the results of the research, several policy recommendations are proposed in each category.

Regarding cooperation and networking, the creation of thematic clusters or functional cooperation networks among SMEs operating in similar or related sectors could open up new opportunities to share resources, reduce costs and combine production capacity to produce larger orders, to compete with large companies, to share knowledge and to find solutions for common problems. To facilitate cooperation, co-working spaces or hubs could be created for rural SMEs, providing premises, office equipment and business consultations. A good example can be found in the north-east of the United Kingdom (for more see Cowie et al. 2013).

Information and training activities should include regular consultations and other "innovation motivation" activities for rural SMEs. Business success and failure stories should be shared at "business breakfast or lunch", providing an opportunity for rural entrepreneurs to meet and exchange experience. Training programmes should focus on new business models and innovations and on the use of ICT and social media for distribution and marketing. Training should be adjusted to the time periods when there is less work in the fields or it should be provided online. Finally, innovation culture should be promoted among local pupils and the youth, the future entrepreneurs.

Regarding innovation support programmes, permanent innovation support measures should be available for rural SMEs all year round. "Innovation Vouchers" should be introduced, providing small scale support for the development of innovations. Similarly, "Design Vouchers" could offer small scale support for the creation of competitive design and branding of products, whereas "ICT Innovation Vouchers" would help introducing ICT in the business model (e.g. creating a website, enhancing supply chain management and customer relationship management with ICT tools). Innovation support measures should be available not only to agricultural SMEs, but to any company operating in a rural area. Special support measures should be offered for rural SMEs performing social and environmental functions, as well as to people (including youngsters) willing to start their business in rural areas.

Marketing and sales promotion in international markets could be promoted by recruiting sales agents or sales promotion assistants abroad. Advice and assistance should be available to rural SMEs to start cooperating with foreign business partners. Informative webpages should be created to inform about business and investment opportunities within particular regions. Brands should be created for rural regions to promote the products of rural SMEs and business cooperation possibilities.

Last but not least, to improve the availability of workforce, the cooperation between rural SMEs and vocational education institutions should be expanded. A temporary recruitment of highly professional employees and managers, within such initiatives as "Rent a boss", could be introduced in rural regions. Diversity 
management and smart and flexible work initiatives within rural SMEs should be encouraged. Distant work (e-work) should be promoted as it allows knowledge economy professionals to live and work in rural areas, while maintaining a job in companies operating in the urban areas. Finally, social campaigns should be undertaken to change the perception of the countryside and promote it as a highquality place to live.

The main barriers and challenges of rural SMEs in adopting innovations and corresponding policy recommendations are summarised in Table 1.

\section{Table 1. Main barriers, challenges and policy recommendations for the introduction of innovations in rural SMEs}

\begin{tabular}{|c|c|}
\hline Barriers and challenges & Policy recommendations \\
\hline $\begin{array}{l}\text { Shortcomings in the environment for innovation: } \\
\text { Lack of innovation culture; } \\
\text { Low interest in innovative solutions; } \\
\text { Weak interaction between business, science, public sector. }\end{array}$ & $\begin{array}{l}\text { Cooperation and networking: } \\
\text { Creation of thematic clusters or functional cooperation } \\
\text { networks of SMEs; } \\
\text { Establishment of co-working spaces or hubs in rural areas. }\end{array}$ \\
\hline $\begin{array}{l}\text { Inappropriate innovation policies and support measures: } \\
\text { Fragmentation and discontinuity of innovation policies and } \\
\text { support measures; } \\
\text { Lack of competence in public sector to build efficient } \\
\text { innovation programmes; } \\
\text { Focus of the rural support programmes on the agricultural } \\
\text { sector; } \\
\text { Administrative burden within the innovation support measures. }\end{array}$ & $\begin{array}{l}\text { Innovation support programmes: } \\
\text { Permanent innovation support measures for SMEs all year } \\
\text { round; } \\
\text { Introduction of "Innovation Vouchers", "Design Vouchers" and } \\
\text { "ICT Innovation Vouchers"; } \\
\text { Support for all SMEs operating in the rural areas; } \\
\text { Special support measures for the rural SMEs performing social } \\
\text { and environmental functions; } \\
\text { Special support measures for people (including youngsters) } \\
\text { willing to start their business in rural areas. }\end{array}$ \\
\hline $\begin{array}{l}\text { Lack of knowledge and skills within companies: } \\
\text { Lack of information and knowledge on the use of innovative } \\
\text { solutions; } \\
\text { Lack of general knowledge on funding instruments; } \\
\text { Insufficient number of business advisers and experts for the } \\
\text { rural SMEs; } \\
\text { Poor exchange of good practices between the rural SMEs; } \\
\text { Lack of time to look for education opportunities and participate } \\
\text { in training; } \\
\text { Missing ICT skills for the older generation. }\end{array}$ & $\begin{array}{l}\text { Information and training: } \\
\text { Regular consultations and other "innovation motivation" } \\
\text { activities; } \\
\text { Regular "business breakfasts or lunches" for experience sharing } \\
\text { and networking; } \\
\text { Information and best practice sharing on the use of funding } \\
\text { instruments; } \\
\text { Training programmes focusing on new business models and } \\
\text { innovations; } \\
\text { Training programmes focusing on the use of ICT and social } \\
\text { media; } \\
\text { Promotion of innovation culture among local pupils and youth. }\end{array}$ \\
\hline $\begin{array}{l}\text { Difficulties to hire skilled work force: } \\
\text { Lack of highly qualified staff in the countryside; } \\
\text { High turnover of employees, especially in the rural areas close } \\
\text { to cities; } \\
\text { Loss of young people in rural areas. }\end{array}$ & $\begin{array}{l}\text { Availability of workforce: } \\
\text { Expansion of cooperation between rural SMEs and vocational } \\
\text { education institutions; } \\
\text { "Rent a boss" for innovation development; } \\
\text { Introduction of diversity management; } \\
\text { Smart and flexible work initiatives; } \\
\text { Promotion of the countryside as a high-quality place to live. }\end{array}$ \\
\hline $\begin{array}{l}\text { Weak capacity to compete/low competitiveness: } \\
\text { Focus on low prices instead of quality improvements; } \\
\text { Inability to invest in advertising the high-quality products of } \\
\text { rural SMEs; } \\
\text { Limited capacity to negotiate a fair price with retailers. }\end{array}$ & $\begin{array}{l}\text { Marketing and sales promotion in international markets: } \\
\text { Sales agents or sales promotion assistants in external countries; } \\
\text { Advice and assistance to start cooperating with foreign business } \\
\text { partners; } \\
\text { Informative webpages presenting business opportunities in } \\
\text { particular regions; } \\
\text { Creation of identity or a branding of rural regions. }\end{array}$ \\
\hline
\end{tabular}

Šaltinis: sudaryta autorių.

\section{Conclusions}

1. Despite the differences in geography and the economic development level, rural 
SMEs around Europe experience similar challenges in their transition to the knowledge economy.

2. The main challenges for rural SMEs in adopting innovative technologies and new business models are shortcomings in the environment for innovation, inappropriate innovation policies and support measures, lack of knowledge and skills within companies, difficulties to hire new skilled work force and low competitiveness compared to their urban counterparts.

3. There are various new opportunities for rural SMEs, including multifunctional agriculture, rural tourism, agro-tourism, social farming, local authentic products, bioeconomy, sharing economy, territorial marketing, use of online platforms, networking and collaboration.

4. Public policies should be improved in areas, such as cooperation and networking, information and training, innovation support programmes, marketing and sales promotion and availability of workforce to support rural SMEs in raising their competitiveness and productivity, thus building a 'new rural economy' with a strong innovative spirit in thriving rural communities.

\section{References}

1. Adamowicz, M. Bio-Economy as an Element of Development Strategies in the European Union. Economic Science for Rural Development Conference Proceedings, 2017, 44: 237-247.

2. Arnone, M., Cavallaro, C. The Challenge of a Place-and Network-Based Approach to Development in Italian regions. Procedia-Social and Behavioral Sciences, 2016, 223: 31-36.

3. Bonciu, F., Balgar, A.C. Sharing Economy as a Contributor to Sutainable Growth. An EU Perspective. Romanian Journal of European Affairs, 2016, 16(2): 36-45.

4. Ceapraz I.L., Delhoume C. How Social Capital Can Improve the Territorial Innovation? The Case of the French Agriculture. Some Conceptual Issues. Romanian Journal of Regional Science, 2017, 11(2): 26-35.

5. Cei, L., Stefani, G., Defrancesco, E., \& Lombardi, G. V. Geographical Indications: A First Assessment of the Impact on Rural Development in Italian NUTS3 Regions. Land Use Policy, 2018, 75: 620-630.

6. Cimdina, A. Unnoticed Entrepreneurship and Innovation in Latvia's Rural Economy. Journal of Baltic Studies, 2014, 45(1):79-104.

7. Connect to Grow. Supporting SME Growth Through Innovation and Partnership: A Review of the Landscape. Last Modified August 9, 2016. https://businessfightspoverty.org/articles/supporting-sme-growth-through-innovationand-partnership/ [2018-12-10].

8. Cowie P., Thompson N. and Rowe F. Honey Pots and Hives: Maximising the potential of rural enterprise hubs. Centre for Rural Economy. Newcastle: Newcastle University, 2013.

9. Felicetti, M. Cultural Innovation and Local Development: Matera as a Cultural District. Procedia-Social and Behavioral Sciences, 2016, 223: 614-618. 
10. Fieldsend A. F. Rural Renaissance: An Integral Component of Regional Economic Resilience. Studies in Agricultural Economics, 2013, 115: 85-91.

11. Galloway, L. Can Broadband Access Rescue the Rural Economy? Journal of Small Business and Enterprise Development, 2007, 14:641-653.

12. Hanappi-Egger, E. Shall I Stay or Shall I Go? On the Role of Diversity Management for Women's Retention in SET Professions. Equality, Diversity and Inclusion: An International Journal, 2012, 31(2): 144-157.

13. Ionela G.P., Constantin B.M, Lia-Dorica Dogaru L.D. Advantages and Limits for Tourism Development in Rural Area (Case Study Ampoi and Mure Valleys). Procedia Economics and Finance, 2015, 32:1050 - 1059.

14. Kruszilicika M., Verginia Chiritescu V., Gavrilescu C., Viorica Gavrila V., Andrei D. R. The Structure of the Rural Economy in Romania. Case Study on Macro-Region 2. Bulletin UASVM Agriculture, 2014, 71(1): 76-82.

15. Kubickova L., Moravkova M., Tuzova M., Necas I. The Role of Small and Medium Sized Enterprises in the Development of Rural Areas. Acta Universitatis Agriculturae et Silviculturae Mendelianae Brunensis, 2017, 65(6): 1987 - 1996.

16. Lanfranchi M., Giannetto C. Sustainable Development in Rural Areas: The New Model of Social Farming. Calitatea, 2014, 15(S1): 219-223.

17. Lopez M. \& Pastor R. Development in Rural Areas Through Capacity Building and Education for Business. Procedia-Social and Behavioral Sciences, 2015, 197: 18821888.

18. Miceikiene A. Review on International \& National Conferences and Seminars. Rural development 2017: Bioeconomy Challenges. Transformations in Business and Economics, 2017, 16(3): 286 - 289.

19. Privitera, D. Describing the Collaborative Economy: Forms of Food Sharing Initiatives. Economic Science for Rural Development Conference Proceedings, 2016, 43: 92-98.

20. Singh S., Bhowmick B. An Exploratory Study for Conceptualization of Rural Innovation in Indian Context. Procedia-Social and Behavioral Sciences, 2015, 207: 807-815.

21. Smallbone D., Baldock R., North D. Policy Support for Small Firms in Rural Areas: The English Experience. Environment and Planning C: Government and Policy, 2003, 21: 825-841.

22. Smallbone D., North D. Innovation and New Technology in Rural Small and MediumSized Enterprises: Some Policy Issues. Environment and Planning C: Politics and Space, 1999, 17(5): 549 - 566.

23. Sumedrea S. Are Cultural and Gender Diversity Drivers of Firms Performance in Post Crises Emergent Economies? Studia Universitatis Babes - Bolyai Oeconomica, 2017, 62(1): $61-75$.

24. Szetela B., Mentel G. May the Sharing Economy Create a New Wave of Globalization? Economic Annals-XXI, 2016, 161 (9/10): 31-34.

25. Tarasovych L., Tamuliene V. Marketing as a Tool for Social and Economic Rural Areas Development. Management Theory and Studies for Rural Business and Infrastructure Development, 2017, 39 (4): 524-536.

26. Tate G. Entrepreneurship and the Environment for Rural SMEs in the Shropshire Hills, 
UK, 1997-2009. The Journal of Entrepreneurship, 2010, 19(2): 191 - 207.

27. Teece D. J. Business Models and Dynamic Capabilities. Long Range Planning, 2017, 51: $40-49$.

28. Tisserant, P., Wagner, A. L., and Barth, I. The Propensity to Discriminate: A Diagnostic Indicator for Diversity Management. Equality, Diversity and Inclusion: An International Journal, 2013, 32(1): 36-48.

29. Wondrak M. and Segert A. Using the Diversity Impact Navigator to Move from Interventions Towards Diversity Management Strategies. Journal of Intellectual Capital, 2015, 16 (1): 239 - 254.

30. Zawadzka A. K. Making Small Towns Visible in Europe: The Case of CITTASLOW Network - The Strategy Based on Sustainable Development. Transylvanian Review of Administrative Sciences Dec. 2017, Special Issue: 90-106.

Inga Uvarova, Alise Vitola

\section{Europos kaimo vietovių mažų ir vidutinių įmonių inovacijų konkurencingumas ir galimybès}

Abstract

Naujovių diegimas atlieka pagrindinị vaidmenį transformuojant kaimo vietoves žinių ekonomikos link. Tačiau mažos ir vidutinès kaimo įmonès (MVIt) susiduria su ịvairiais įššūkiais, kurie trukdo diegti naujoves. Straipsnyje analizuojami pagrindiniai iššs̄kiai ir galimybès, diegiant inovacijas mažose ir vidutinèse kaimo įmonėse. Straipsnyje panaudota informacija, apimanti šešias Europos šalis (Bulgariją, Čekijos Respubliką, Vengriją, Italiją, Latviją ir Slovėniją). Pagrindiniai naujovių diegimo vidutinèse kaimo įmonėse iššūkiai yra inovacijų aplinkos trūkumas, netinkama inovacijų politika ir paramos priemonès, sunkumai samdant naujus, kvalifikuotus darbuotojus bei mažas konkurencingumas, lyginant su miesto partneriais. Todèl siūlomos politikos rekomendacijos yra skirtos inovacijų skatinimui kaimo MVİ, sutelkiant dėmesị i bendradarbiavimą ir darbą tinkle. Kitos svarbios priemonès turètų būti orientuotos ị informacijos sklaidą ir mokymą, viešąsias inovatyvias programas, rinkodarą ir pardavimų skatinimą.

Inga Uvarova is lecturer and Head of the Business Incubator at the BA School of Business and Finance in Riga.

E-mail: inga.uvarova@gmail.com

Alise Vitola is lecturer and post-doctoral researcher at the Hotel School Riga.

E-mail: vitola.alise@gmail.com

Inga Uvarova yra Verslo ir finansų mokyklos Rygoje lektoré, verslo inkubatoriaus vadovè.

E. paštas: inga.uvarova@gmail.com

Alise Vitola yra Rygos viešbučių mokyklos lektorè, podoktorantūros stažuotoja ir 


\section{tyrëja.}

E. paštas: vitola.alise@gmail.com

Straipsnis įteiktas redakcijai 2018 m. lapkričio mėn.; recenzuotas; parengtas spaudai 2019 $\mathrm{m}$. vasario mèn. 